\title{
Additive Model of Aboveground Biomass of Larch Single-Trees Related To Age, Dbh and Height, Sensitive to Temperature and Precipitation in Eurasia
}

\section{${ }^{1,2}$ VLADIMIR. A. USOLTSEV; ${ }^{1}$ SEYED OMID REZA SHOBAIRI; ${ }^{1}$ ANNA. A. OSMIRKO; ${ }^{2}$ IVAN. S. TSEPORDEY ; ${ }^{1}$ VIKTOR. P. CHASOVSKIKH}

\author{
${ }^{1}$ Ural State Forest Engineering University Sibirskii trakt str., 37, Yekaterinburg, 620100 Russian Federation \\ ${ }^{2}$ Botanical Garden, Russian Academy of Sciences, Ural Branch, 8 Marta str., 202a, \\ Yekaterinburg, 620144 Russian Federation \\ *Corresponding Author Email: omidshobeyri214@gmail.com
}

\begin{abstract}
The first attempt of modeling changes in the aboveground additive component composition of larch (genus Larix spp.) tree biomass, according to the Trans-Eurasian hydrothermal gradients of Eurasia on the database compiled for the structure of harvest biomass in a number of 510 sample trees is fulfilled. The adequacy of the obtained regularities is determined by the level of variability 87-99 \% explained by the proposed regression models. For the central territory of European Russia, characterized by the mean annual temperature of January $-10{ }^{\circ} \mathrm{C}$ and the mean annual precipitation of 400 $\mathrm{mm}$, the increase in temperature by $1{ }^{\circ} \mathrm{C}$ at the constant level of precipitation causes on Larix spp. trees of the equal age and sizes, the decrease in the aboveground, stem, needle and branches by $0.4,0.3,1.4$ и $1.3 \%$, respectively. For the same region, in equal-sized trees, the increase in precipitation by $100 \mathrm{~mm}$ at a constant annual temperature in January causes the decrease of the aboveground and stem biomass by 1.2 and $1.7 \%$, respectively, and the increase of needle and branches biomass by 4.0 and $6.0 \%$, respectively. The development of such models for the main forest-forming species of Eurasia will make it possible to predict changes in the productivity of the forest cover of Eurasia in connection with climate change.
\end{abstract}

\section{DOI: https://dx.doi.org/10.4314/jasem.v24i10.8}

Copyright: Copyright (C) 2020 Oyedpo et al. This is an open access article distributed under the Creative Commons Attribution License (CCL), which permits unrestricted use, distribution, and reproduction in any medium, provided the original work is properly cited.

Dates: Received: 15 August 2020; Revised: 22 September 2020; Accepted: 19 October 2020

Keywords: larch trees, genus Larix spp., tree biomass, allometric models.

Forest biomass is an important part of sustainable development and the main driver of succession changes in secondary forests (Lohbeck et al. 2015), but the rate of recovery of their biomass is significantly faster than the rate of biodiversity recovery (Martin et al. 2013). This means a decrease in the stability of the biosphere and its gradual degradation, which poses a threat to human existence. Therefore, the removal of uncertainties related to the assessment of forest cover biological productivity and biodiversity is of paramount importance. Since the 19th century, researchers have noted that the relationships between the mass of individual parts and the whole organism in different species are well described by the so-called self-similarity function, or allometric one (Snell 1892, Dubois 1897, Huxley 1932, Gould 1966, Zar 1968, Ishchenko 1969, Mina and Клевезаль 1976, Kofman 1986, Gelashvili et al. 2013). Recently, a comparative analysis of the accuracy of different methods for determining the biological productivity of some tree species was fulfilled, and it was shown that allometric models designed at a tree scale give a smaller prediction error compared to models performed at the forest stand scale (Zeng et al. 2018). Such allometric models for mixed stands are particularly relevant.
However, when calculating allometric models of tree biomass there is always a residual variance, reflecting, in particular, the discrepancy between the annual dynamics of the crown mass, especially of the foliage, and the relative conservatism of $D$, as an accumulator of its annual increments (Usoltsev 1988), as well as differences of age status, soil and climatic conditions. As shown by Kolmogorov (1933), the correlation measures only parallelism in the variability of variables, the source of which can be the action of the third variable, and in relation to such a complex object as a forest ecosystem, such "third" factors can be a great number. Having the aim of improving the accuracy of regional allometric models, one begins to involve in such models as predictors, along with $D$, such variables as average temperature and precipitation, which have, as it is well known, the geographical locality. Such models are called models sensitive to climate variables. However, they are presented as single, very seldom studies (Forrester et al. 2017, Zeng et al. 2017). All above mentioned models are internally contradictory, they are not harmonized by the biomass structure, i.e. they do not provide the additivity of component composition, according to which the total biomass of components

\footnotetext{
*Corresponding Author Email: omidshobeyri214@gmail.com
} 
(stems, branches, needles, roots) obtained by "component" equations would be equal to the value of biomass obtained by the total biomass equation (Dong et al. 2015). The need to respect the principle of additivity in the tables compiled for tree biomass on relevant equations, it was observed already in the first papers devoted to the evaluation of the biomass of trees (Young et al. 1964). In order to ensure the principle of additivity in the calculation of systems of equations for estimating the biomass of trees, several methods of their structuring are proposed. Models structured according to the principle "from particular to general" are divided into three groups: linear additive, nonlinear additive and nonlinear multiplicative (Kurucz 1969, Kozak 1970, Parresol 1999). An alternative variant, structured "from general to particular", has recently been suggested (Tang et al., 2000). The structure of the disaggregated additive model is proposed, according to which the estimated aboveground biomass is divided into components (stem with bark, tree crown, branches, foliage) in accordance with their shares in the aboveground biomass. If estimates of intermediate biomass components are desirable, the estimated aboveground biomass is subdivided into intermediate components (e.g., stem and crown) according to their shares in the aboveground biomass. Further, the estimated biomass of the stem is divided into wood and bark according to their shares in the stem biomass, and the estimated biomass of the crown is divided into branches and foliage according to their shares in the crown biomass (Zheng et al. 2015). The influence of climate change on the biomass of trees of a particular tree species in the format of additive models according to trans-continental hydrothermal gradients has not been studied at all. In this study, the first attempt of modeling changes in the additive component composition of tree aboveground biomass according to hydrothermal Trans-Eurasian gradients is made. In the modeling process the database of biomass of 520 larch trees (genus Larix spp.) was used (Usoltsev 2016).

\section{MATERIALS AND METHODS}

Of the 520 sample trees described in the abovementioned database containing data on biomass and dendrometric parameters, 420 trees were selected for the analysis, including six species-vicariants of the genus Larix spp. Their distribution by regions, tree species and mensuration indices is presented in Table 1. One hundred trees from the database were omitted in our analysis due to the lack of height measurements.

Table 1. Distribution of the 420 larch sample trees by ecoregions, tree species and mensuration indices

\begin{tabular}{|c|c|c|c|c|c|}
\hline \multirow[b]{2}{*}{ Regions } & \multirow{2}{*}{$\begin{array}{l}\text { Species of the } \\
\text { genus Larix spp.* }\end{array}$} & \multicolumn{3}{|c|}{ Ranges of: } & \multirow[b]{2}{*}{-Data number } \\
\hline & & age, yrs & diameter $D, \mathrm{~cm}$ & tree height, $\mathrm{m}$ & \\
\hline$\overline{\text { West Europa }}$ & L. decidua Mill. & $34 \div 210$ & $7.1 \div 47.8$ & $9.8 \div 34.0$ & 19 \\
\hline European Russia & L. sukaczewii N.Dyl. & $10 \div 70$ & $1.0 \div 35.0$ & $2.3 \div 28.0$ & 25 \\
\hline Turgay deflection & L. sukaczewii N.Dyl. & $26 \div 42$ & $6.2 \div 28.0$ & $7.9 \div 17.8$ & 28 \\
\hline North of West Siberia & $\begin{array}{l}\text { L. sibirica } \mathrm{L} \text {. } \\
\text { L. gmelinii } \text { Rupr. }\end{array}$ & $10 \div 70$ & $2.1 \div 38.0$ & $2.9 \div 24.8$ & 116 \\
\hline North of Eastern Siberia & L. cajanderi Mayr. & $44 \div 400$ & $0.3 \div 22.7$ & $1.4 \div 14.8$ & 66 \\
\hline North of Russian Far East & $\begin{array}{l}\text { L. cajanderi Mayr. } \\
\text { L. gmelinii Rupr. }\end{array}$ & $30 \div 424$ & $3.9 \div 52.8$ & $2.9 \div 30.0$ & 43 \\
\hline Mongolia, China & $\begin{array}{l}\text { L. sibirica } \mathrm{L} \text {. } \\
\text { L. gmelinii Rupr. }\end{array}$ & $14 \div 186$ & $0.5 \div 31.0$ & $1.5 \div 24.3$ & 50 \\
\hline Japan & L. leptolepis Gord. & $9 \div 56$ & $4.0 \div 35.9$ & $4.3 \div 26.7$ & 73 \\
\hline
\end{tabular}

Table 2. The structure of the two-step additive model, sold under proportional weighting (Zheng et al. 2015, Dong et al. 2015). Symbols

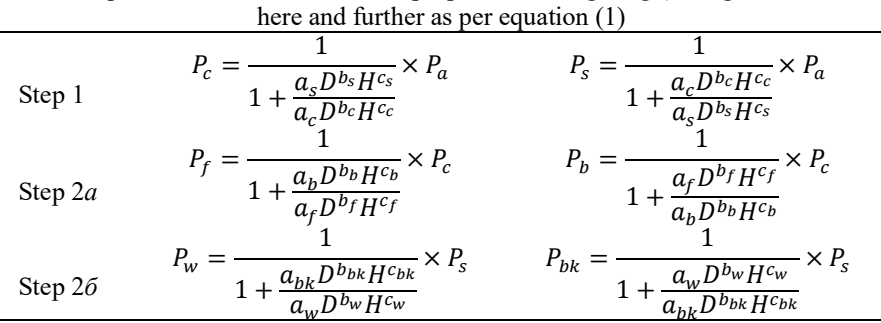

where $P_{i}$ is biomass of $i$-th component, $\mathrm{kg} ; A$ is tree age, $y \mathrm{rs} ; D$ is stem diameter at breast height, $\mathrm{cm} ; \mathrm{H}$ is tree biomass, $m ; i$ is the index of biomass component: aboveground (a), crown (c), foliage (f), branches (b), stem above bark (s), stem wood (w) and stem bark (bk); T is mean January temperature, ${ }^{\circ} \mathrm{C} ; \mathrm{PR}$ is mean annual precipitation, $\mathrm{mm}$.

VLADIMIR. A. USOLTSEV; SEYED OMID REZA SHOBAIRI; ANNA. A. OSMIRKO; IVAN. S. TSEPORDEY; VIKTOR. P. CHASOVSKIKH 
Based on the information in Table 2, the structure of the regression model is suggested as in eqn. 1 :

$$
\begin{aligned}
& \ln P_{i}=a_{0 i}+a_{1 i}(\ln A)+a_{2 i}(\ln D)+a_{3 i}(\ln H)+a_{4 i} \\
& (\ln D)(\ln H)+a_{5 i}[\ln (T+50)]+a_{6 i}(\ln P R),
\end{aligned}
$$

Each sample plot on which tree biomass estimating was performed is positioned relatively to the isolines of the mean January temperature (Fig. 1) and relatively to the isolines of mean annual precipitation (Fig. 2). The matrix of harvest data was compiled, in which the biomass component values and mensuration tree parameters were related with the corresponding values of mean January temperature and precipitation, then included in the regression analysis procedure.

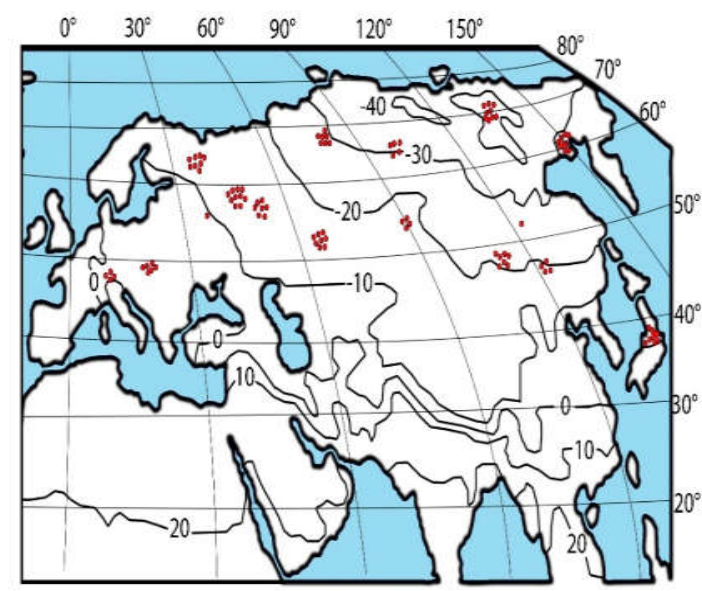

Fig 1. Distribution of biomass harvest data of 420 larch sample trees on the map of the mean January temperature, ${ }^{\circ} \mathrm{C}$ (World Weather Maps, 2007;

https://store.mapsofworld.com/image/cache/data/map_2014/current s-and-temperature-jan-enlarge-900x700.jpg)

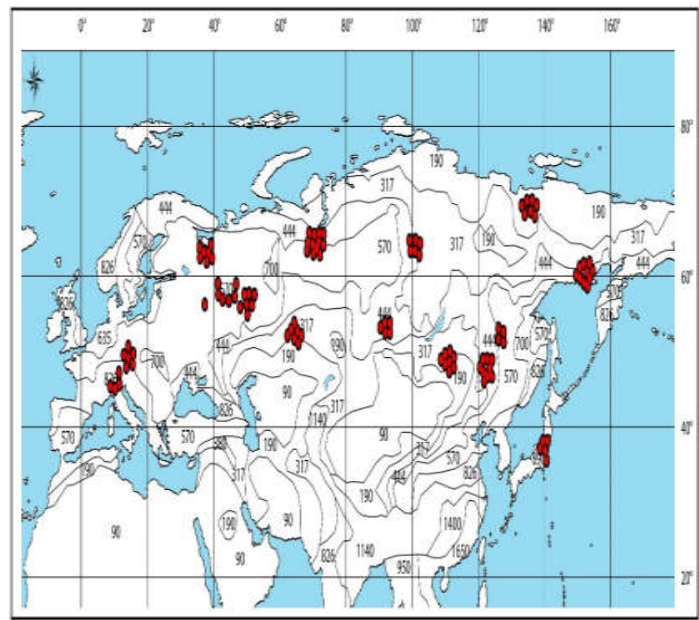

Fig 2. Distribution of biomass harvest data of 420 larch sample trees on the map of the mean annual precipitation, $\mathrm{mm}$ (World Weather Maps, 2007).
As noted above, the main predictor included in the allometric model of biomass is usually the stem diameter at breast height $D$. In this study, the task is to extract the climatic component from the residual dispersion of a model obtained during to calculation of tree biomass only by stem diameter. To made climatic factors to be predominant and "recoverable" from this "information noise", it is necessary to take into account in the model, in addition to the diameter, also tree height and age, which are factors that determine the structure of its biomass too (Nikitin 1965, Usoltsev 1972). According to the structure of the disaggregation two-step additive model (Zheng et al. 2015), the aboveground biomass $P_{a}$ estimated by an initial equation is subdivided into components according to the scheme presented in Table 2. Since the mean January temperature in the northern part of Eurasia has negative values, the corresponding independent variable is modified to the form $(T+50)$ to be subjected to $\log$-log procedure. The schematic map of the isolines of mean January temperature, rather than the mean annual temperature, is used, since climate warming is most pronounced in the cold half of the year (Golubyatnikov and Denisenko 2009, Laing and Binyamin 2013, Felton et al. 2016). Along with the three main forest-forming variables - tree age, diameter and height - , the product of variables $(\ln D)(\ln H)$ was introduced as an additional predictor, the need for which was shown earlier (Usoltsev et al., 2017).

\section{RESULTS AND DISCUSSION}

Characteristic of equations (1) is obtained by the common regression analysis, and after correcting on logarithmic transformation by G. L. Baskerville (1972) and anti-log transforming is given in the Table 3. All regression coefficients of equations (1) are characterized by the significance level of 0.05 and better, and the resulting equations are adequate to the original values presented in the available database. The obtained initial equations (1) are transformed to the additive form according to the above mentioned algorithm (see Table 2) by two-step additive systems of disaggregation equations (Zheng et al. 2015). The final form of the transcontinental additive model of the component composition of the larch tree biomass is shown in Table 4. Since it was established (Cunia and Briggs 1984; Reed and Green 1985) that the elimination of the internal inconsistency of biomass equations by ensuring their additivity does not necessarily means the increase in the accuracy of its estimates, it is necessary to clarify whether the obtained additive model is adequate enough and how its characteristics relate to the indices of the adequacy of initial equations?

VLADIMIR. A. USOLTSEV; SEYED OMID REZA SHOBAIRI; ANNA. A. OSMIRKO; IVAN. S. TSEPORDEY; VIKTOR. P. CHASOVSKIKH 
Table 3. Characteristics of initial equations (1)

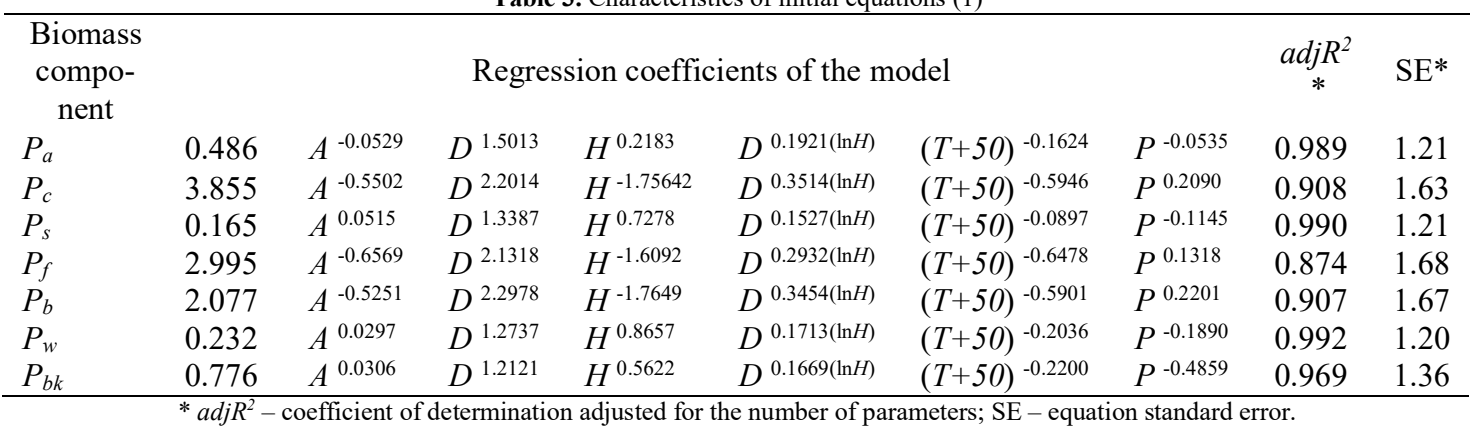

Table 4. Final two-step additive model of tree biomass

\begin{tabular}{ccccc} 
& $P_{a}=$ & $0.486 A^{-0.0529} D^{1.5013} H^{0.2183} D^{0.1921(\ln H)}(T+50)^{-0.1624} P^{-0.0535}$ & \\
Step & $P_{c}=$ & $0.165 A^{0.0515} D^{1.3387} H^{0.7278} D^{0.1527(\ln H)}(T+50)^{-0.0897} P^{-0.1145}$ & $\times P_{a}$ \\
1 & $P_{s}=$ & $3.855 A^{-0.5502} D^{2.2014} H^{-1.75642} D^{0.3514(\ln H)}(T+50)^{-0.5946} P^{0.2090}$ & $\times P_{a}$ \\
& & 1 & 1 & \\
Step & $P_{f}=$ & $2.077 A^{-0.5251} D^{2.2978} H^{-1.7649} D^{0.3454(\ln H)}(T+50)^{-0.5901} P^{0.2201}$ & $\times P_{c}$ \\
$2 a$ & $P_{b}=$ & $2.995 A^{-0.6569} D^{2.1318} H^{-1.6092} D^{0.2932(\ln H)}(T+50)^{-0.6478} P^{0.1318}$ & $\times P_{c}$ \\
& $P_{w}=$ & $0.776 A^{0.0306} D^{1.2121} H^{0.5622} D^{0.1669(\ln H)}(T+50)^{-0.2200} P^{-0.4859}$ & $\times P_{s}$ \\
Step & & 1 & \\
$2 \sigma$ & $P_{b k}=$ & $0.232 A^{0.0297} D^{1.2737} H^{0.8657} D^{0.1713(\ln H)}(T+50)^{-0.2036} P^{-0.1890}$ & $\times P_{s}$ \\
\hline
\end{tabular}

$A=\exp \{4.4904+0.6404(\ln D)-1.6043[\ln (T+50)]+0.5231(\ln P R)\} ; \operatorname{adj} R^{2}=0.621 ; S E=1.70(2) ;$

$$
H=\exp \{0.0648+0.0597(\ln A)+0.6372(\ln D)+0.2493[\ln (T+50)]-0.0467(\ln P R)\} ; \operatorname{adj} R^{2}=0.895 ; S E=1.21 \text {. }
$$

For this purpose both the additive model (see Table 4) and the initial equations (see Table 3), are tabulated on the actual data of age, stem diameter, height, and climatic variables, and the obtained calculated biomass values are compared with the actual ones according to $R^{2}$. The results of the comparison shown in the Figure 3 , indicate that the additive system of equations have shown higher adequacy for all biomass components in comparison with initial ones. Due to the many times greater complexity of measuring the age and height of trees in comparison with $D$, one uses specially designed equations or tables (Usoltsev 1988). For this purpose, equations (2) and (3) is calculated to estimate the tree age $A$ by the known value of the stem diameter $D$, as well as to estimate the tree height $H$ by the known value of the tree age $A$ and stem diameter $D$. Our analysis of the configuration of the surfaces obtained in three-dimensional space in Figure 4 allows to draw some nontrivial conclusions. Thus, in all thermal (zonal) belts (in the range of $T$ from $-40^{\circ} \mathrm{C}$ to $0^{\circ} \mathrm{C}$ ) with increasing precipitation, the aboveground biomass and stem mass decreases, but the mass of tree needles and branches increases. Regardless of the level of precipitation during the transition from warm zones $(T$ $\left.=0^{\circ} \mathrm{C}\right)$ to cold ones $\left(T=-40^{\circ} \mathrm{C}\right)$ all the biomass components increase. The obtained models of larch tree biomass make them possible to establish quantitative changes in the structure of tree biomass due to climatic changes, in particular, the mean temperature of January and mean annual precipitation. The percentage change in the structure of biomass is associated with the ratio of these two climatic variables. For the central territory of European Russia, characterized by the mean annual temperature of January $-10{ }^{\circ} \mathrm{C}$ and the mean annual precipitation of $400 \mathrm{~mm}$, the increase in temperature by $1{ }^{\circ} \mathrm{C}$ at the constant level of precipitation causes on larch trees at the age of 100 years with a diameter of $24 \mathrm{~cm}$ and stem height of $22 \mathrm{~m}$, the decrease in the aboveground, stem, needle and branches by $0.4,0.3,1.4$ and $1.3 \%$, respectively. For the same region, in equal-sized trees, the increase in precipitation by $100 \mathrm{~mm}$ at a constant annual temperature in January causes the decrease of the aboveground and stem biomass by 1.2 and $1.7 \%$, respectively, and the increase of needles and branches biomass by 4.0 and $6.0 \%$, respectively. In Figure 5 it is shown the change in the tree biomass $(\Delta, \%)$ with an increase in temperature by $1{ }^{\circ} \mathrm{C}$ in different ecoregions, 
characterized by different values of temperature and precipitation. It is assumed that climate change does not affect precipitation, which changes only geographically (by regions), and the temperature as a result of the expected climate change increases by $1^{\circ} \mathrm{C}$ at different territorial (zonal) temperature levels, designated as $-40 \Delta \ldots 0 \Delta$. Figure 5 shows the general pattern of decrease of all the biomass components of trees with an increase in temperature by $1^{\circ} \mathrm{C}$ in all temperature zones of Eurasia and in all regions that differ in precipitation. These trends are most pronounced in cold zones $\left(T=-40^{\circ} \mathrm{C}\right)$ than in warm ones $\left(T=0^{\circ} \mathrm{C}\right)$.

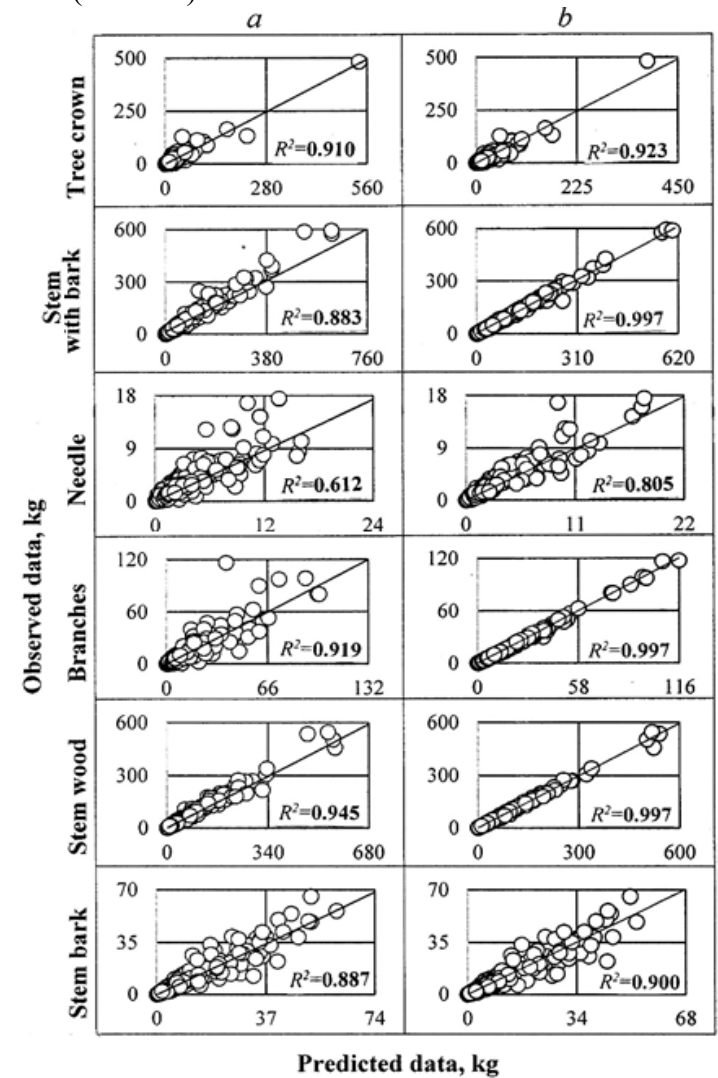

Fig 3. The ratio of the harvest biomass and its values obtained by calculating the initial $(a)$ and additive $(b)$ models of the larch tree biomass.

Since the tabulation of equations (1) using the given values $A, D, H, T$ and $P R$ results in a too cumbersome table, the required figures of the tree biomass dependence upon temperature $T$ and precipitation $P R$ are constructed as a fragment for trees having the age $A$ equal 100 years, diameter $D$ equal $24 \mathrm{~cm}$ and $H$ equal $22 \mathrm{~m}$ (Figure 4). In Figure 6 it is shown the change of tree biomass $(\Delta, \%)$ with the increase in precipitation by $100 \mathrm{~mm}$ in areas characterized by different values of temperature and precipitation. It is assumed that the
January temperature changes only geographically, and precipitation as a result of the expected climate change increases by $100 \mathrm{~mm}$ at different territorial levels of precipitation, designated as $200 \Delta \ldots 900 \Delta$.

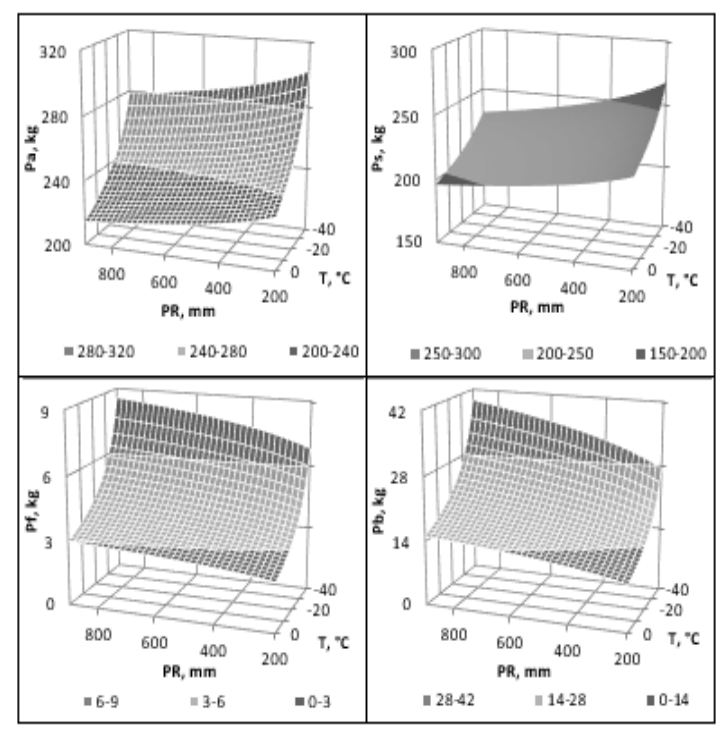

Fig 4. Dependence of larch tree biomass upon the January mean temperature $(T)$ and precipitation $(P R)$. Designations: $P a, P s, P f$, and $P b$ are correspondingly biomass: aboveground, stems, foliage, and branches, $\mathrm{kg}$

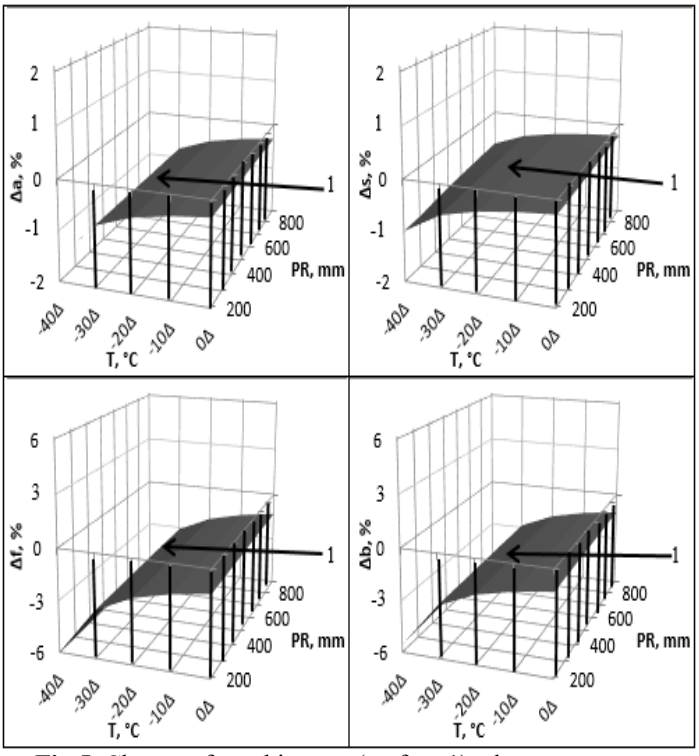

Fig 5. Change of tree biomass (surface 1) when temperature increasing by $1{ }^{\circ} \mathrm{C}$ due to the expected climate change at different territorial levels of temperature and precipitation. Symbols $\Delta a, \Delta s$, $\Delta f$ and $\Delta b$ on the ordinate axes mean the change $( \pm \%)$ of biomass of aboveground, stems, needles and branches, respectively, with the temperature increase by $1{ }^{\circ} \mathrm{C}$ and at the constant precipitation.

Figure 6 shows the common pattern of reducing the aboveground and stem biomass and of increasing the

VLADIMIR. A. USOLTSEV; SEYED OMID REZA SHOBAIRI; ANNA. A. OSMIRKO; IVAN. S. TSEPORDEY; VIKTOR. P. CHASOVSKIKH 
mass of needles and branches with an increase in annual precipitation by $100 \mathrm{~mm}$ in all temperature zones of Eurasia and in all regions that differ in precipitation. The trends mentioned are most strongly expressed in dry areas $(P R=200 \mathrm{~mm})$ than in enough wet ones $(P R=900 \mathrm{~mm})$.

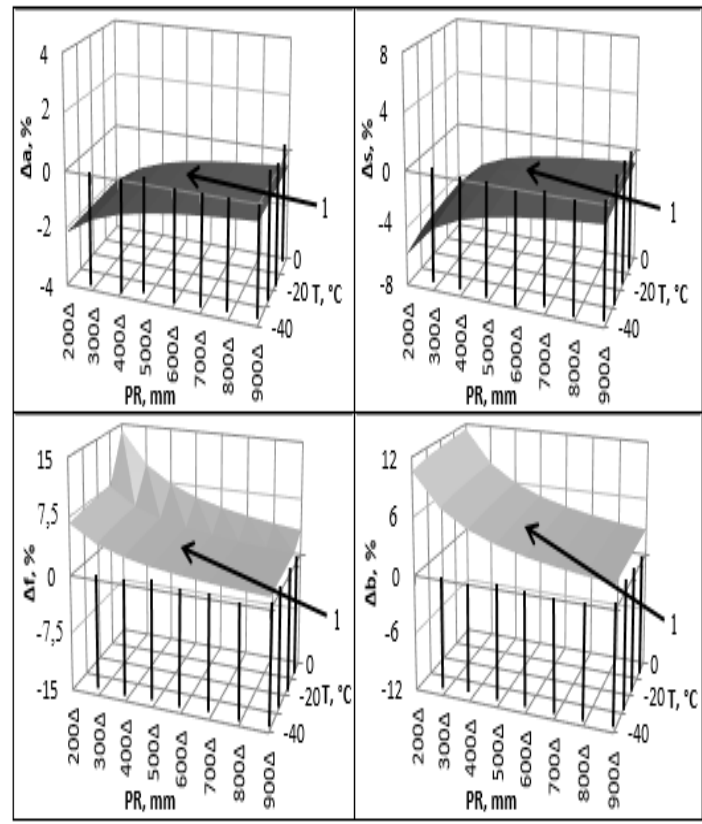

Fig 6. Change of tree biomass (surface 1) when precipitation increasing by $100 \mathrm{~mm}$ due to the expected climate change at different territorial levels of temperature and precipitation. The symbols $\Delta a, \Delta s, \Delta f$ and $\Delta b$ along the ordinate axes represent the change $( \pm \%)$ of aboveground, stems, needles and branches

biomass, respectively, with precipitation increase by $100 \mathrm{~mm}$ and at the constant mean temperatures of January.

Our results only partially confirm the previously published data (Zeng et al. 2017) on the change in the aboveground biomass of larch trees with the increase in temperature by $1^{\circ} \mathrm{C}$ and with the increase in precipitation by $100 \mathrm{~mm}$. In particular, the allometric model, which includes the diameter and stem height as independent variables, was developed for aboveground and underground biomass on the basis of 600 trees of eight larch species (genus Larix spp.) harvested throughout China. After introduction into the allometric model the indices of the mean annual temperature and precipitation, as additional independent variables, it is established that the temperature increase by $1^{\circ} \mathrm{C}$ leads to an increase in the aboveground biomass of equal-sized trees by $0.9 \%$, and an increase in precipitation by $100 \mathrm{~mm}$ causes a decrease in the above- biomass by $1.5 \%$ (Zeng et al. 2017). According to our results, there is a decrease in the aboveground biomass with an increase in both temperature and precipitation. We have found that in
Russia the temperature raising by $1^{\circ} \mathrm{C}$ gives an decrease in the tree aboveground biomass by $0.4 \%$, and an increase in precipitation by $100 \mathrm{~mm}$ causes its decrease by $1.2 \%$. Thus, the aboveground biomass of larch in the boreal forests of Russia reacts negatively to the temperature increase, and in the temperate and subtropical forests of China reacts positively. With increasing precipitation, the aboveground biomass of trees in Russia and China is reduced, and in Russia compared with the forests of China it is to a lesser extent $(1.2<1.5)$. In another study devoted to European forests (Forrester et al. 2017), there was no statistically significant effect of temperature and precipitation on the tree biomass of the most components. The reasons may be the following: a small range of temperature and precipitation variations within Europe, a study of species groups instead of a single species, the introduction of too many variables and their combined effects into the model, and the use of meta-data instead of harvest biomass indices. The study of the regional variability of the allometric models of aboveground biomass of trees of Masson pine in southern China showed that diameter at breast height, together with the long-term average of growing season temperature, total growing season precipitation, mean temperature of wettest quarter, and precipitation of wettest quarter, had significant effects on values of aboveground biomass. Excessive precipitation during the growing season and high mean temperature in the wettest quarter reduced the aboveground biomass, while a warm growing season and abundant precipitation in the wettest quarter increased it (Fu et al. 2017). Thus, the reaction of pine biomass to the increase in precipitation in the subtropical conditions of China in the wettest quarter is negative, and in the wettest quarter at extremely high temperatures is positive. A similar differentiated reaction of biomass and net primary production to temperature and precipitation was shown earlier on the example of stands of twoneedled pines in Eurasia (Usoltsev et al. 2019).

Conclusions: Thus, we have made the first attempt to simulate changes in the component composition of the additive aboveground biomass of larch trees by TransEurasian hydrothermal gradients. The obtained models of larch tree aboveground biomass make it possible to establish quantitative changes in the structure of larch biomass due to climatic changes, in particular, the mean January temperature and mean annual precipitation. They explain $87-99 \%$ of the variability in tree biomass.

Acknowledgements: This paper was prepared within the programs of the current scientific research of the Ural Forest Engineering University and Botanical 
Garden of the Ural Branch of Russian Academy of Sciences.

\section{REFERENCES}

Baskerville, GL (1972). Use of logarithmic regression in the estimation of plant biomass. Can. J. For. Res. 2: 49-53.

Cunia, T; Briggs, RD (1984). Forcing additivity of biomass tables: some empirical results. Can. J. For. Res. 14: 376-384.

Dong, L; Zhang, L, Li, F (2015). A three-step proportional weighting system of nonlinear biomass equations. For. Sci. 61(1): 35-45.

Dubois, E (1897). Sur le rapport du poids de l'encéphale avec la grandeur du corps chez les mammifères. Bull. Soc. d'anthropol. de Paris. 8: 337-376.

Felton, A; Nilsson, U; Sonesson, J; Felton, AM; Roberge, J-M; Ranius, T; Ahlström, M; Bergh, J; Bjorkman, C; Boberg, J; Drössler, L; Fahlvik, N; Gong, P; Holmström, E; Keskitalo, ECH; Klapwijk, MJ; Laudon, $\mathrm{H}$; Lundmark, T; Niklasson, M; Nordin, A; Pettersson, M; Stenlid, J; Sténs, A; Wallertz, K (2016). Replacing monocultures with mixed-species stands: Ecosystem service implications of two production forest alternatives in Sweden. Ambio. 45(Suppl. 2): 124-139.

Forrester, DI; Tachauer, IHH; Annighoefer, P; Barbeito, I; Pretzsch, H; Ruiz-Peinado, R; Stark, H; Vacchiano, G; Zlatanov, T; Chakraborty, T; Saha, S; Sileshi, GW (2017). Generalized biomass and leaf area allometric equations for European tree species incorporating stand structure, tree age and climate. For. Ecol. Manage. 396: 160-175.

Fu, L; Lei, Y; Wang, G; Bi, H; Tang, S; Song, X (2016). Comparison of seemingly unrelated regressions with error-invariable models for developing a system of nonlinear additive biomass equations. Trees. 30(3): 839-857.

Gelashvili, DB; Iudin, DI; Rosenberg, GS; Yakimov, VN; Solntsev, LA (2013). Fractals and multifractals in bioecology. Nizhny Novgorod, Publishing House of Nizhny Novgorod State University, Russia.

Golubyatnikov, LL; Denisenko, EA (2009). Influence of climatic changes on the vegetation of European
Russia. News of Rus. Acad. Sci. Geogr. Ser. 2: 5768.

Gould, S (1966). Allometry and size in ontogeny and phylogeny. Biol. Rev. 41: 587-640.

Huxley, J (1932). Problems of relative growth. Methuen \& Co., London.

Ishchenko, VG (1969). Application of allometric equations in population ecology of animals. Proc. Inst. Ecol. Plants Anim. Ural branch, Russian Academy of Sciences. Issue 71: Questions of evolutionary and population ecology of animals. Sverdlovsk: 8-15.

Kofman, GB (1986). Growth and form of trees. Novosibirsk, Nauka publ., Russia

Kolmogorov, AN (1933). On the question of suitability of the forecast formulas found by statistical methods. Zavodskaya Laboratoriya. Factory Laboratory. 1: 164-167.

Kozak, A (1970). Methods for ensuring additivity of biomass components by regression analysis. For. Chron. 46(5): 402-404.

Kurucz, J (1969). Component weights of Douglas-fir, western hemlock, and western red cedar biomass for simulation of amount and distribution of forest fuels. University of British Columbia, Forestry Department, M.F. thesis.

Laing, J; Binyamin, J (2013). Climate change effect on winter temperature and precipitation of Yellowknife, Northwest Territories, Canada from 1943 to 2011. Am. J. Clim. Change. 2: 275-283.

Lohbeck, M; Poorter, L; Martinez-Ramos, M; Bongers, F (2015). Biomass is the main driver of changes in ecosystem process rates during tropical forest succession. Ecology. 96: 1242-1252.

Martin, PA; Newton, AC; Bullock, JM (2013). Carbon pools recover more quickly than plant biodiversity in tropical secondary forests. Proc. of the Royal Soc.: B (Biol. Sci.). 280: 1-8

Mina, NV; Klevezal, GA (1976). Growth of animals. Moscow, Nauka publ., Russia

Nikitin, KE (1965). Forest and mathematics. Lesnoe Khozyaistvo [Forest Management], 5: 25-29. 
Parresol, BR (1999). Assessing tree and stand biomass: a review with examples and critical comparison. For. Sci. 45: 573-593.

Reed, DD; Green, EJ (1985). A method of forcing additivity of biomass tables when using nonlinear models. Can. J. For. Res. 15: 1184-1187.

Snell, O (1892). Die Abhängigkeit des Hirngewichtes von dem Körpergewicht und den geistigen Fähigkeiten. Archiv für Psychiatrie und Nervenkrankheiten. 23: 436-446.

Tang, S; Zhang, H; Xu, H (2000). Study on establish and estimate method of compatible biomass model. Sci. Silv. Sin. 36: 19-27 (in Chinese with English abstract).

Usoltsev, VA (1972). Birch and aspen crown biomass in forests of Northern Kazakhstan. Vestnik Selskokhozyaistvennoi Nauki Kazakhstana. Bull. Agric. Sci. Kazakhstan. 4: 77-80.

Usoltsev, VA (1988). Growth and structure of forest stand biomass. Novosibirsk, Nauka Publ., Russia (http://elar.usfeu.ru/handle/123456789/3352).

Usoltsev, VA (2016). Single-tree biomass data for remote sensing and ground measuring of Eurasian forests. CD-version in English and Russian. Yekaterinburg, Ural State Forest Engineering University. (http://elar.usfeu.ru/handle/123456789/6103).

Usoltsev, VA; Kolchin, KV; Voronov, MP (2017). Dummy variables and biases of allometric models when local estimating tree biomass (on an example of Picea L.). Eko-Potencial. 1(17): 22-39.
Usoltsev, VA; Shobairi, SOR; Tsepordey, IS; Chasovskikh, VP (2019). Modelling forest stand biomass and net primary production with the focus on additive models sensitive to climate variables for two-needled pines in Eurasia. J. Clim. Change, 5(1): 41-49

World Weather Maps (2007). URL: https:/www.mapsofworld.com/referrals/weather/.

Young, HE; Strand, L; Altenberger, R (1964). Preliminary fresh and dry weight tables for seven tree species in Maine. Maine Agricultural Experiment Station, Technical Bulletin 12.

Zar, JR (1968). Calculation and miscalculation of the allometric equation as a model in biological data. BioSci. 18(12): 1118-1120.

Zeng, WS; Chen, XY; Pu, Y; Yang XY (2018). Comparison of different methods for estimating forest biomass and carbon storage based on National Forest Inventory data. For. Res. 31(1): 6671 (in Chinese with English abstract).

Zeng, WS; Duo, HR; Lei, XD; Chen, XY; Wang, XJ; $\mathrm{Pu}, \mathrm{Y}$; Zou, WT (2017). Individual tree biomass equations and growth models sensitive to climate variables for Larix spp. in China. Europ. J. For. Res. 136(2): 233-249

Zheng, C; Mason, EG; Jia, L; Wei, S; Sun, C; Duan, J (2015). A single-tree additive biomass model of Quercus variabilis Blume forests in North China. Trees. 29(3): 705-716 